\title{
Projecting the external health costs of a coal-fired power plant: The case of Kusile
}

\author{
Johannes W Riekert \\ Steven F Koch \\ Department of Economics, University of Pretoria
}

\begin{abstract}
We examine an important subset of the expected health costs associated with the commissioning of Kusile, a new coal-fired electricity generation plant in South Africa. The subset of health impacts focuses on sulphur dioxides, nitrous oxides and large particulate matter (greater than $10 \mathrm{~mm}$ ). The analysis makes use of the Impact Pathway Approach combined with the data transfer methodology. The plant, which is expected to contribute $4800 \mathrm{MW}$ of additional electricity to the South African grid is found to have modest health impacts, partly due to the limited additional pollutant emissions expected at the plant. Specifically, additional localised external health costs are found to be in the region of $0.09 \mathrm{c} / \mathrm{kWh}$ to $6.08 \mathrm{c} / \mathrm{kWh}$. Limitations of the analysis are also examined.
\end{abstract}

Keywords: Impact Pathway Approach; health cost externalities; Kusile

\section{Introduction}

The potent mixture of economic development and a lack of investment in its power generation infrastructure and capacity has resulted in South Africa reaching its maximum electricity production capacity. Faced with this challenge, the national power utility, Eskom, has commissioned a number of new power plants to be constructed over the next five years (Department of Energy, 2009). The construction of two new coal-fired power plants - Kusile in eMalahleni, Mpumalanga and Medupi in Lephalale, Limpopo - is underway. South African reliance on coal for electricity generation will therefore increase substantially. 1

The combustion process produces large quanti- ties of gaseous and solid waste that are mainly released into the air, or disposed of in large ash dumps or sludge and slurry ponds. The gaseous emissions contain a potent mixture of pollutants. Various studies have shown these pollutants to have adverse effects through air pollution (Pope, III et al., 2009; Dominici et al., 2006; Van Horen, 1996) and water pollution (Van Horen, 1996), adverse effects on biodiversity (Zvereva et al., 2008; Turpie et al., 2004), adverse effects on buildings (Charola et al., 2007; Van Horen, 1996; Schreurs, 2011), and to contribute towards global climate change (Turpie et al., 2004). To add fuel to the fire, so to speak, burning coal produces one and a half times the $\mathrm{CO}_{2}$ emissions of oil combustion and twice the amount of $\mathrm{CO}_{2}$ emissions from natural gas combustion, while producing the same amount of energy (Epstein et al., 2011). This difference holds true for many other pollutants produced during the electricity generation process.

With regards to solid waste, ash dumps have been found to contribute to air pollution, particularly in the form a particulate matter (PM) when fly ash from ash dumps is carried into the atmosphere by the wind. Sludge and slurry pools have also been linked to ground water contamination, which has a variety of health and environmental consequences (Epstein et al., 2011). With this in mind, coal-fired power plants are a major contributor to atmospheric pollution levels. Multiple local and international studies have sought to quantify the socio-economic and environmental damages associated with pollutants from coal-fired electricity generation. We add to this literature, through the examination of the potential health effects that could arise from one new coal-fired power generation plant - Kusile, specifically, the localised health impacts and costs associated with these impacts. The analysis is based upon the Impact Pathway Approach (IPA). 
In order to assess the full cost related to Kusile all of the above-mentioned externalities would have to be considered. This paper therefore forms part of a set of papers which aim to provide a comprehensive overview of the external cost associated with Kusile (Blignaut, 2012; Inglesi-Lotz \& Blignaut, 2012; Nkambule \& Blignaut, 2012).

The remainder of this study continues with an examination of previous literature, in Section 2. Section 3 describes the Impact Pathway Approach and the underlying assumptions of the analysis. Section 4 presents the results of the analysis and a brief discussion of the results and a conclusion are presented in Section 5.

\section{Literature review}

Growth and development necessitates the production of electricity. As the need for electricity rises with development, questions regarding potential side effects have also begun to surface. Consequently, over the past three decades, identifying and quantifying the externalities associated with electricity generation and the impact of a growing electricity sector have come to the fore. Externalities arise when the social and marginal costs of electricity generation differ, which means that the market price does not fully reflect the resource value. Therefore, individual welfare does not reflect the entire cost of the good or service (Baumol and Oats, 1988; Pearce and Turner, 1990). The focus of this study is on health externalities, specifically the cost of health externalities.

\subsection{Health consequences of pollution}

The combustion of coal during the electricity generation process produces carbon dioxide $\left(\mathrm{CO}_{2}\right)$, carbon monoxide $(\mathrm{CO})$, methane $\left(\mathrm{CH}_{4}\right)$, particulate matter $(\mathrm{PM})$, oxides of nitrogen $\left(\mathrm{NO}_{\mathrm{x}}\right)$, sulphur dioxide $\left(\mathrm{SO}_{2}\right)$, mercury $(\mathrm{Hg})$, and a wide range of carcinogenic chemicals and heavy metals (Levy et al., 2009). While the chemical nature of PM is important, it varies significantly, prompting researchers to use the diameter of the particulates, as this affects lung penetration (Norman et al., 2007). ${ }^{2}$ In epidemiological studies, $\mathrm{PM}_{2.5}$ and $\mathrm{PM}_{10}$ are most often selected as relevant exposure metrics (Norman et al., 2007).

Significant associations have been found between outdoor air pollution levels and morbidity and mortality outcomes. Various epidemiological studies find these pollutants to contribute to bronchitis, asthma and lung cancer, and also hospital admissions or emergency room visits related to respiratory ailments, cardiac conditions, asthma, coronary obstructive pulmonary disease (Norman et al., 2007; Levy et al., 2009; Epstein et al., 2011). While there is a link between pollutant exposure and deteriorating health, attributing the incidence of epidemiological outcomes to specific pollutants is com- plex, mainly due to strong correlations found between the various pollutants in high concentrations (Sarnat et al., 2001). Therefore, a pollutantby-pollutant incidence analysis could greatly overestimate the health impacts of air pollution (Künzli et al., 2000). ${ }^{3}$

\subsection{Costing methodologies}

There are two fundamental approaches to evaluating externalities, namely, the abatement cost approach and the damage cost approach. The abatement cost approach considers the cost of controlling damage, as a proxy for the actual damages. Although limited data is needed, low levels of accuracy also arise (Owen, 2004). The top-down and the bottom-up damage cost approaches, which use actual costs and benefits that can be tied to the externality rather than the cost of avoiding that damage, are more common. Top-down estimates use aggregate data, and are, therefore, not relevant for site-specific evaluations. A bottom-up approach, also referred to as the Impact Pathway Approach (IPA), track pollutants from their initial source and monetise their effects (Thopil \& Pouris, 2010). As this approach allows for site-specific evaluation, it is the method used in this study; further discussion of the method and requirements are presented in Section 3.

\subsection{International studies}

The bulk of electricity sector externality studies focus on the United States (Oak Ridge National Laboratory and Resources for the Future [ORNL/RfR], 1995; Rowe et al., 1994) and various countries in Europe (ETSU, 1995; Friedrich and Voss, 1993; Hohmeyer, 1988; Ottinger et al., 1991; Pearce et al., 1992). Table 1 provides a price-adjusted summary, in ranges, from a number of international externality studies and indicates the study method of each. Included within each range is a value for the health cost externalities. Our comments, however, focus on the method applied in this research, the bottom-up approach. ${ }^{4}$

ORNL/RfF (1995) is representative of early attempts at the bottom-up approach, and focused on the impacts of air pollution on human health and other non-environmental damages. Owing to their inability to control for a number of environmental impacts, the damage cost estimates are low, which highlights the need for further evaluation efforts. The RCG/Tellus initiative (Rowe et al., 1995) applies a similar method for New York. Although not necessarily improving on ORNL/RfF, RCG/Tellus developed EXMOD which is a useful computerised model. The modelling was further developed, when the European commission and the US Department of Energy launched the EC/US Fuel Cycles Study in 1991 (Thopil \& Pouris, 2010), referred to as the ExternE program. Earlier ExternE 
Table 1: Selected external studies of coal-fired electricity using different approaches Source: Thopil and Pouris (2010:2)

\begin{tabular}{lllr}
\hline Study & Method & Region & $\begin{array}{c}\text { External cost } \\
\text { USc/kWh }\end{array}$ \\
\hline Schuman \& Cavanagh (1982) & Abatement cost & United States & $0.07-54.64$ \\
\hline Hohmeyer (1988) & Top-down damage cost & Germany & $12.42-28.33$ \\
\hline Ottinger et al. (1991) & Top-down damage cost & United States & $4.04-10.99$ \\
\hline Pearce et al. (1992) & Top-down damage cost & UK & $3.31-17.89$ \\
\hline Faaij et al. (1998) & Top-down damage cost & The Netherlands & 4.93 \\
\hline ORNL/RfF (1995) & Bottom-up damage cost & United States & $0.14-0.60$ \\
\hline European Commission (1995) & Bottom-up damage cost & UK/Germany & $1.21-2.96$ \\
\hline Rowe et al. (1994) & Bottom-up damage cost & United States & 0.38 \\
\hline Bhattacharyya (1997) & Bottom-up damage cost & India & 1.68 \\
\hline European Commission (1999) & Bottom-up damage cost & European Union & $1.04-89.80$ \\
\hline Maddison (1999) & Bottom-up damage cost & UK/Germany & $0.38-0.88$ \\
\hline Rafaj \& Kypreos (2007) & Bottom-up damage cost & Global average & 9.08 \\
\hline Klaassen \& Riahi (2007) & Bottom-up and top-down & Global average & 4.84 \\
\hline Dutkiewicz \& De Villiers (1993) & Top-down damage cost & South Africa & 0.481 \\
\hline Van Horen (1996) & Bottom-up damage cost & South Africa & $1.03-5.77^{1}$ \\
\hline Spalding-Fecher \& Matibe (2003) & Bottom-up damage cost & South Africa & $0.40-2.68^{1}$ \\
\hline Note: 1) Values are given in terms of 2006 US cents, as based on the 2006 Rand/US\$ middle rate. & \\
\hline
\end{tabular}

studies (European Commission, 1995; European Commission, 1999) made substantial advances in the methodologies associated with valuation and provide deeper insight into the data and pathway requirements for environmental externality valuation.

\subsection{South African studies}

Thopil and Pouris (2010) provide a useful summary of electricity externality analysis in South Africa. Electricity externalities were first addressed and quantified by Dutkiewicz and De Villiers (1993) in a Department of Minerals and Energy Affairs study. Their top-down approach finds costs that could be placed in the lower range of international studies, although they suggest that the inclusion of aesthetic effects (e.g. noise pollution) could improve the analysis. Van Horen (1996) is the most extensive electricity externality study to date; with an emphasis on coal and nuclear power, using the bottom-up approach to compare the external costs across these different forms of electricity generation. The study found that the release of greenhouse gasses (GHG) contributes the most to the external costs, while the health impact of air emissions contribute to a lesser extent. However, Van Horen argues for the use of more relevant dose-response functions and the inclusion of the cost of air pollution stemming from ash dumps.

Spalding-Fecher and Matibe (2003) and Spalding-Fecher (2005) expanded Van Horen's analysis, including the incorporation of updated power generation infrastructure data and the external benefits associated with household electrification through, for example, the decreased inhalation of smoke from indoor fires. Despite these improvements, Spalding-Fecher and Matibe (2003) suggest further refinements, such as the use of impact pathways more suited to the South African context, as well as local dose-response functions. The estimates from these three studies are presented at the end of Table 1 , based on inflation-adjusted values presented in Thopil and Pouris (2010). As with the previous studies, health externalities are included within these costs.

\section{Data and methodology}

As noted earlier, this analysis is based on the IPA (Rowe et al., 1994; European Commission, 1999; Rafaj and Kypreos, 2007; Klaassen and Riahi, 2007), which follows pollutants from their initial source, estimates their impacts and calculates monetary values related to these impacts. Given that the IPA corresponds with the real-world sequence of events and consequences associated with electricity generation, it is intuitively appealing and is generally regarded as the benchmark model (Rowe et al., 1995), although there are limitations. The approach is data-intensive, requiring professional judgements regarding the data; and as such, the results can be sensitive to these judgements. Relatedly, studies of this nature are best conducted when data is readily available and impact pathways are easily established. Although Van Horen (1996), as well as Spalding-Fecher and Matibe (2003), suggest revision to the impact pathways and dose-response 
functions in South Africa, Van Horen (1996) further notes that there is a large body of relevant information available in South Africa making an IPA evaluation possible.

In order to quantify the health impacts caused by the pollutants released by a coal-fired power plant, information for the four major steps in the IPA is required. These steps, as summarised by Van Horen (1996), are: (i) determine power station pollution emissions; (ii) track pollutant dispersion and deposition; (iii) evaluate dose responses to pollution exposure; and (iv) value the increased morbidity and mortality associated with those dose responses. Once monetary values have been linked to morbidity and mortality, the bridge between market cost and social cost can be, at least partially, addressed.

\subsection{Emissions}

In South Africa, low quality coal, which would otherwise have little other economic use (Van Horen, 1996), is the energy source for electricity generation. ${ }^{5}$ The coal is laid down in thick level seams at shallow depths, such that extraction is relatively cheap and easy; however, in addition to its low quality the coal also has a high ash content (Department of Energy, 2010). ${ }^{6}$ The exact content of ash and sulphur is not available at the power plant level. Since the exact composition of the emissions cannot be precisely determined, $\mathrm{PM}_{2.5}$ and $\mathrm{PM}_{10}$ are most often used to represent human exposure to air pollution (Norman et al., 2007). Owing to data limitations, only $\mathrm{PM}_{10}$ will be used to represent $\mathrm{PM}$, while $\mathrm{SO}_{2}$ and $\mathrm{NO}_{2}$ will also be considered in this analysis. ${ }^{7}$
Since the Kusile plant is yet to be completed, emissions data is based on experiences from the Kendal coal-fired power station, located in close proximity to Kusile. Comparing Kendal and Kusile, based on their technical and operational specifications it is clear that the two plants are rather similar (see Tables 2 and 3). In Tables 2 and 3, two different capacity values are used for Kusile, reflecting the difference between the actual capacity (4 $800 \mathrm{MW}$ ) and the environmental impact assessment (EIA) calculation capacity (5 $400 \mathrm{MW}$ ). Since the volume of emissions is linearly related to the capacity of the plant, multiplying the emission data with the ratio of the two capacities ( $4800 / 5 \quad 400=0.8889$ ) yields projected emissions for Kusile. These emissions contribute to the overall ambient pollution levels in the area and, therefore, are used in the dispersion model (see Table 4).

\subsection{Dispersion}

The dispersion of pollutants is determined by the physical characteristics of the plant (i.e. chimney stack height; the speed, volume and temperature of gas emissions; and ash dump characteristics) and atmospheric conditions (i.e. wind patterns, mixing heights and atmospheric stability) (Van Horen, 1996). Dispersion models indicate ambient concentrations of various pollutants across time and space, following the exit of emissions from the chimney stack. These models are typically local, focussing on a $50 \mathrm{~km}$ radius from the plant. Beyond this distance, the pollutants are depleted through chemical transformation, dry deposition and precipitation. While the Gaussian plume model is often used to

Table 2: Technical specifications for Kendal and Kusile power plants Source: Wassung (2010: 10-13)

\begin{tabular}{lccccc}
\hline Power plant & Province & Capacity & Cooling system & $\begin{array}{c}\text { Pollution control } \\
\text { technology }\end{array}$ & Year \\
\hline Kendal & Mpumalanga & $4116 \mathrm{MW}$ & Indirect dry & ESP ${ }^{2}$ & 1993 \\
\hline Kusile & Mpumalanga & $4800 \mathrm{MW}{ }^{1}$ & Direct dry & ESP $^{2}$, FGD $^{3}$ & $2014-18$ \\
\hline Notes: & & & & \\
$\begin{array}{l}\text { 1. Actual capacity of Kusile. } \\
\text { 2. Electrostatic precipitator for controlling dust. }\end{array}$ & & & \\
3. Flue gas desulphurisation for controlling $\mathrm{SO}_{2}$. & & & \\
\hline
\end{tabular}

Table 3: Stack parameters for Kendal and Kusile plants Source: Thomas and Scorgie (2006: 4.7, 5.3)

\begin{tabular}{lcccccc}
\hline Power station & Capacity & $\begin{array}{c}\text { Number of } \\
\text { stacks }\end{array}$ & $\begin{array}{c}\text { Stack height } \\
(\mathrm{m})\end{array}$ & $\begin{array}{c}\text { Diameter } \\
(\mathrm{m})\end{array}$ & $\begin{array}{c}\text { Exit velocity } \\
(\mathrm{m} / \mathrm{s})\end{array}$ & $\begin{array}{c}\text { Temperature } \\
\left({ }^{\circ} \mathrm{K}\right)\end{array}$ \\
\hline Kendal & $4116 \mathrm{MW}$ & 2 & 275 & 13.51 & 24.08 & 399 \\
\hline Kusile & $5400 \mathrm{MW}^{1}$ & 2 & $150-300^{2}$ & 12.82 & 26 & 403 \\
\hline $\begin{array}{l}\text { Notes: } \\
\text { 1. Proposed capacity used in EIA calculations. } \\
\text { 2. Three stack height scenarios were considered in EIA calculations. }\end{array}$ & & & & \\
\hline
\end{tabular}


Table 4: Total emissions for current operating conditions for $\mathbf{2 0 0 3}$ Source: Thomas and Scorgie (2006: 4.13, 5.3, 5.7)

\begin{tabular}{|c|c|c|c|c|c|c|}
\hline \multirow[t]{2}{*}{ Power station } & \multirow[t]{2}{*}{ Capacity } & \multicolumn{5}{|c|}{ Tonnes per annum } \\
\hline & & $\mathrm{SO}_{2}$ & $N O_{X}$ & NO & $\mathrm{NO}_{2}$ & $P M$ \\
\hline Kendal (2003) & $4116 \mathrm{MW}$ & 321441 & $\mathrm{NQ}^{5}$ & 73282 & 2293 & 3495 \\
\hline Kendal (proposed 2009) & $4116 \mathrm{MW}$ & 336084 & $\mathrm{NQ}^{5}$ & 76620 & 2398 & 3654 \\
\hline Kusile (proposed: EIA) ${ }^{1}$ & $5400 \mathrm{MW}^{3}$ & 364082 & 87,361 & 55835 & 1747 & 7947 \\
\hline$\overline{\text { Kusile (proposed: actual) }}{ }^{2}$ & $4800 \mathrm{MW}^{4}$ & 323628 & 77,654 & 49631 & 1553 & 7064 \\
\hline $\begin{array}{l}\text { Notes: } \\
\text { 1. Assuming } 0 \% \text { control efficie } \\
\text { 2. Figures determined through } \\
\text { 3. Proposed capacity used in } \mathrm{E} \\
\text { 4. Actual capacity of Kusile. } \\
\text { 5. Not quantified. }\end{array}$ & $\begin{array}{l}\text { cy for } \mathrm{SO}_{2} \text {. } \\
\text { calculation: [Kus } \\
\text { A calculations. }\end{array}$ & A) values]*( & 0/5400). & & & \\
\hline
\end{tabular}

estimate local dispersion, it will not be used here. Spalding-Fecher and Matibe (2003) do not believe the model matches the conditions of the Highveld.

Owing to the detailed scientific knowledge required to construct and estimate pollution dispersion models, the dispersion calculations published in Kusile's EIA are used, while existing exposure response functions (ERFs) have been sourced from the literature. The data transfer method is applied, which first requires the identification of existing values that can be transferred into the current study. Second, the appropriateness of the existing values must be evaluated to ensure that the values are suitable. Third, the quality of the studies to be transferred must be assessed, since this will affect the quality of the current study. Lastly, the values may be adjusted to better suit the context of the current study, possibly requiring additional information (Boyle and Bergstrom, 1992). There are, however, some drawbacks to this approach. King and Mazzotta (2000) caution against extrapolating results beyond the scope of the transfer studies. Use of the data transfer method is, however, common when data limitations would make analysis impossible (Sakulniyomporn et al., 2011).

Modelling dispersion patterns require sophisticated software, such as the CALMET/CALLPUFF system. Although not used in this analysis, CALMET/CALLPUFF was used in the air quality impact assessment (AQIA) report (Thomas and Scorgie, 2006) and the EIA (Ninham Shand, 2007). The software consists of three components (Scire et al., 2000): CALMET, CALPUFF and CALPOST. CALMET is a diagnostic meteorological model that generates hourly wind and temperature data. CALPUFF, a multi-layer, multi-species, non-steadystate, Lagrangian Gaussian puff model, uses this data to model movement and variation in pollutant levels. The Lagrangian Gaussian puff model addresses the suitability concerns raised by Spalding-Fecher and Matibe (2003). Lastly, CALPOST summarises the simulation results (Sakulniy- omporn et al., 2011). The dispersion results from the AQIA report are used to identify the at-risk communities surrounding the site of Kusile.

From the AQIA, a number of residential areas have been identified in close proximity to Kusile. The towns of Phola and Ogies are located 10-18 $\mathrm{km}$ east of the site, while numerous smaller areas (including, but not limited to, Voltargo, Cologne, Klippoortjie, Madressa, Witcons, Saaiwater, Tweefontein and Klipplaat) are also nearby (Figure 1). The largest residential area within $30 \mathrm{~km}$ of Kusile is eMalahleni (Ninham Shand, 2007). ${ }^{8}$ Two ambient air quality monitoring stations are operated by Eskom in the region; Kendal 2 and Kendal B are situated within the zone of maximum ground level concentration (GLC), defined as a $25 \mathrm{~km}$ radius around the plant (Ninham Shand, 2007).

For the purpose of this study, the costs associated with $\mathrm{SO}_{2}, \mathrm{NO}_{2}, \mathrm{PM}_{10}$ and a selection of other trace compounds - arsenic (As), chromium VI (Cr $\mathrm{VI})$, lead $(\mathrm{Pb})$ and nickel $(\mathrm{Ni})$ - are considered, since these pollutants are the major contributors to pollution-related health issues. ${ }^{9}$ In order to assess whether pollutant concentrations exceed health thresholds, pollution limits must be defined. Table 5 provides a summary of some maximum and minimum air quality standards in South Africa, as well as the guideline used in the EIA calculations. Since there are numerous local and international air quality standards, only the most and least strict standards, in addition to the standard decided upon in the EIA are given in Table 5.

Although hourly, daily and annual average health standard exceedence data is available, only annual average concentration findings are used, since the cumulative annual health effect and cost of the air pollution are to be considered (see Tables 6, 7 and 8). The base case - that is, this situation without Kusile - as well as three unique scenarios with different stack heights are considered for the pollutants. The scenarios are evaluated in the context of zero $\mathrm{SO}_{2}$ control efficiency and $90 \%$ control 


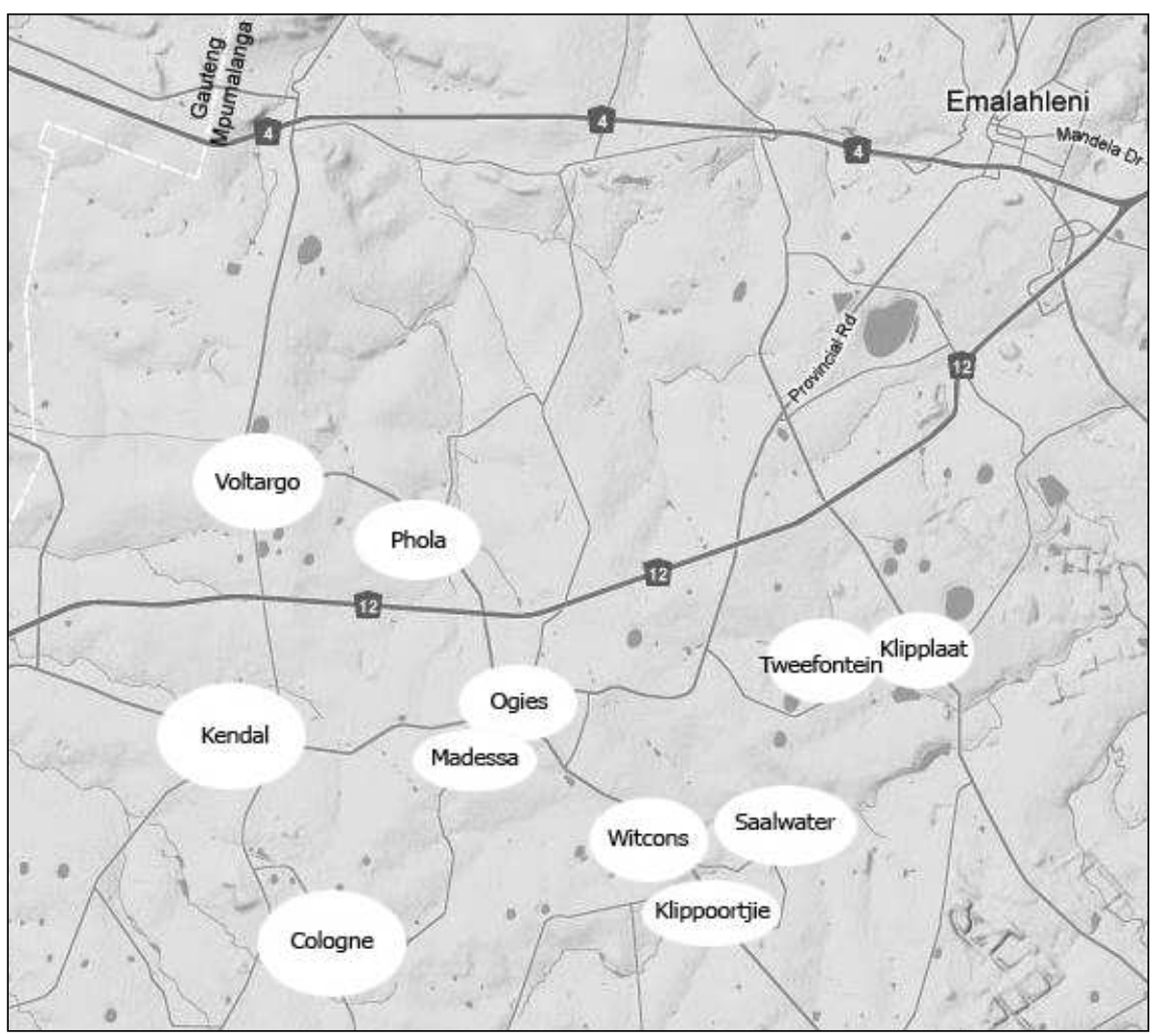

Figure 1: Communities within close proximity of the Kusile power plant and their respective population densities

Source: Thomas and Scorgie (2006:1-6)

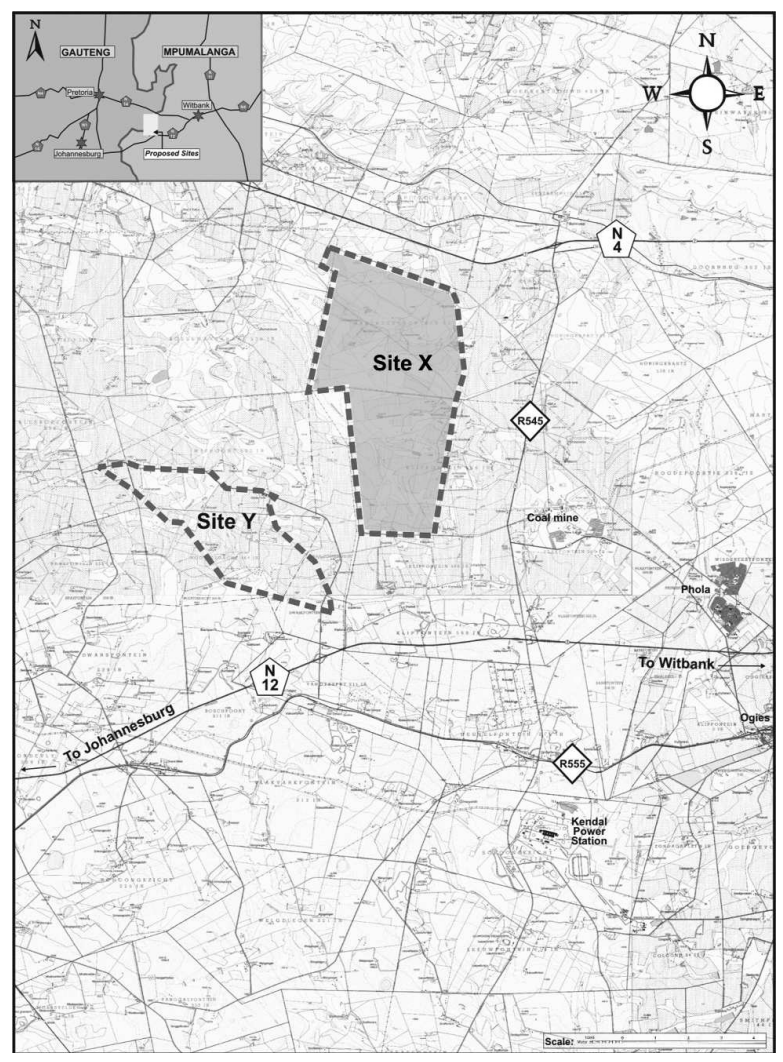

Figure 2: Location of the Kusile power plant (site X)

Source: Ninham Shand (2007: 2)
Table 5: Selected air quality standards (human health only)

Source: Thomas and Scorgie (2006: 2.3, 2.5, 2.7)

\begin{tabular}{|c|c|c|c|}
\hline \multicolumn{4}{|c|}{ Annual average concentrations $\left(\mu \mathrm{gm}^{-3}\right)$} \\
\hline & Minimum & Maximum & EIA \\
\hline $\mathrm{SO}_{2}$ & 20 & 80 & 50 \\
\hline$\overline{\mathrm{NO}_{2}}$ & 40 & 100 & 40 \\
\hline $\mathrm{PM}_{10}$ & 20 & 60 & 40 \\
\hline \multicolumn{4}{|c|}{ Description } \\
\hline$\overline{\mathrm{SO}_{2}}$ & US EPA; WB: TPG & UK; EC & $S A$ \\
\hline$\overline{\mathrm{NO}_{2}}$ & US EPA & UK & $\begin{array}{c}S A, W H O, E C \\
\text { and } U K\end{array}$ \\
\hline $\mathrm{PM}_{10}$ & SA standards & $\mathrm{EC}$ & $\begin{array}{c}\text { SANS, EC } \\
\text { and UK }\end{array}$ \\
\hline
\end{tabular}

efficiency. A positive value means that the annual concentration exceeds the proposed air quality limits. Given the strictest air quality standards, the baseline $\mathrm{SO}_{2}$ concentration exceeds air quality limits. Therefore, even without Kusile's presence, $\mathrm{SO}_{2}$ levels in the area are deemed too high (Ninham Shand, 2007). Exceedence also occurs in the zone of maximum GLC, when considering the EIA air quality standards, although flue gas desulphurisation (FGD) does reduce its magnitude. 
Table 6: Calculated pollutant concentrations for Kusile (4 800 MW)

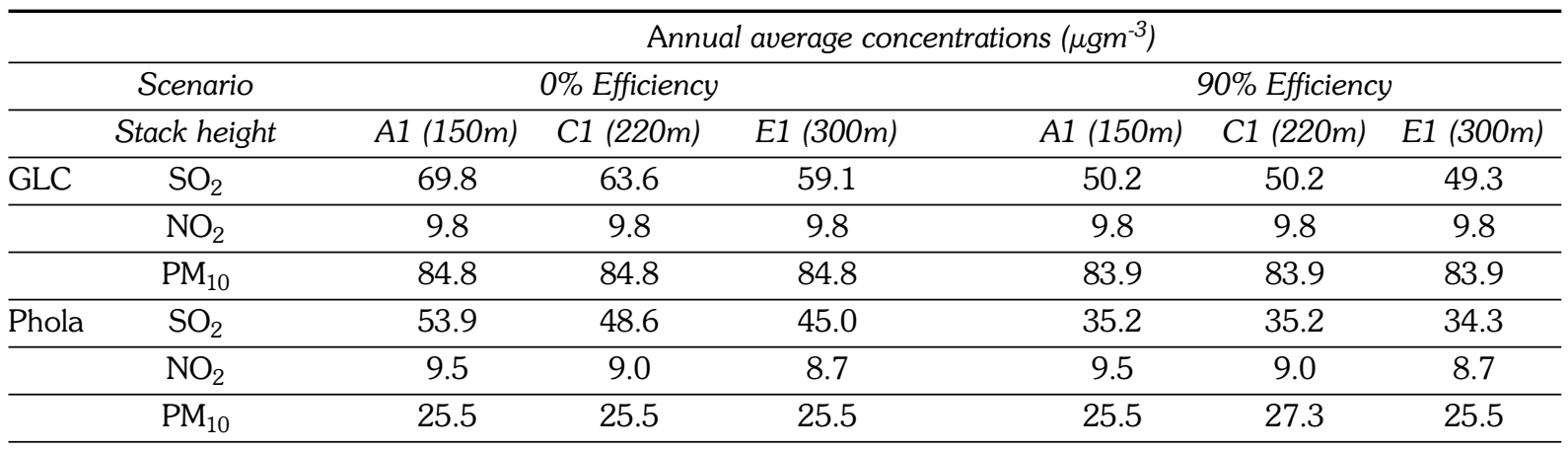

Table 7: Additional pollutant added by Kusile to the baseline conditions

\begin{tabular}{|c|c|c|c|c|c|c|c|}
\hline \multicolumn{8}{|c|}{ Annual average concentrations $\left(\mu \mathrm{gm}^{-3}\right)$} \\
\hline & Scenario & \multicolumn{3}{|c|}{$0 \%$ Efficiency } & \multicolumn{3}{|c|}{$90 \%$ Efficiency } \\
\hline & Stack height & A1 (150m) & C1 (220m) & E1 $(300 m)$ & A1 (150m) & C1 (220m) & $E 1(300 m)$ \\
\hline \multirow[t]{3}{*}{ GLC } & $\mathrm{SO}_{2}$ & 25.8 & 19.6 & 15.1 & 6.2 & 6.2 & 5.3 \\
\hline & $\mathrm{NO}_{2}$ & 1.8 & 1.8 & 1.8 & 1.8 & 1.8 & 1.8 \\
\hline & $\mathrm{PM}_{10}$ & 1.8 & 1.8 & 1.8 & 0.9 & 0.9 & 0.9 \\
\hline \multirow[t]{3}{*}{ Phola } & $\mathrm{SO}_{2}$ & 24.9 & 19.6 & 16.0 & 6.2 & 6.2 & 5.3 \\
\hline & $\mathrm{NO}_{2}$ & 3.6 & 3.1 & 2.8 & 3.6 & 3.1 & 2.8 \\
\hline & $\mathrm{PM}_{10}$ & 19.7 & 19.7 & 19.7 & 19.7 & 21.5 & 19.7 \\
\hline
\end{tabular}

Predicted levels of $\mathrm{NO}_{2}$ do no not exceed even the strictest of air quality standards. The $\mathrm{NO}_{2}$ values for the three scenarios compare very closely to those of the baseline values, suggesting that existing sources of $\mathrm{NO}_{2}$ are the main contributors to ambient levels of the gas.

Particulate matter has a more prominent effect, however. Air quality limits in the GLC zone are always exceeded; all Kusile scenarios exceed the most stringent air quality limit at Phola, as well. Therefore, $\mathrm{PM}_{10}$ could contribute significantly to the incidence of disease related to this pollutant. Table 7 shows the additional pollutants contributed by Kusile above baseline. Only the actual capacity (4 $800 \mathrm{MW}$ ) emissions are considered, and these values are used to determine the number of people affected by various pollution-related illnesses, based on incident rates sourced from the literature (Sakulniyomporn et al., 2011).

Table 8: Aerial concentrations of selected metal compounds

\begin{tabular}{lcc}
\hline Compound & $\begin{array}{c}\text { Annual average concentrations }\left(\mu \mathrm{gm}^{-3}\right) \\
\text { Baseline }\end{array}$ & \begin{tabular}{c} 
Exceedence \\
\hline $\mathrm{As}$
\end{tabular} \\
\hline $\mathrm{Cr} \mathrm{VI}$ & $6.14 \mathrm{E}-05$ & $1.68 \mathrm{E}-05$ \\
\hline $\mathrm{Pb}$ & $6.20 \mathrm{E}-04$ & $3.30 \mathrm{E}-04$ \\
\hline $\mathrm{Ni}$ & $1.29 \mathrm{E}-04$ & $6.44 \mathrm{E}-05$ \\
\hline
\end{tabular}

Finally, Ninham Shand (2007) notes that elevated $\mathrm{SO}_{2}$ concentrations identified in the study have significant potential health risk, particularly when coupled with elevated levels of particulate matter. Although there is a potentially high risk in the Phola residential area, exceedence was infrequent at the reference level, hence, the health effects depend on whether individuals exposed to the pollution are sensitive to the impacts of $\mathrm{SO}_{2}$ at the time of exceedance. Nonetheless, the $\mathrm{SO}_{2}$ levels are cause for concern. ${ }^{10}$

The largest residential populations within the dispersion area are found at Phola and Ogies, although only Phola will be considered on an individual level, since it represents the most significant (in terms of size) residential area within the impact area. Detailed population data on the impact area could not be found and, hence, calculations are based on aggregate data for the eMalahleni Local Municipality, where Kusile is situated. According to MPG (2011), the eMalahleni Local Municipality covers approximately $2677.67 \mathrm{~km}^{2}$ with an estimated 425925 people living in the municipality. The study relies on the population density reported by the EIA, given as a range of between 1000 and 5000 people per $\mathrm{km}^{2}$, which are used for low and high value calculations, respectively.

The zone of maximum GLC covers a $25 \mathrm{~km}$ radius emanating from the plant. Both Phola and Ogies fall within this area. Therefore, any cost estimation in the zone will represent the total cost of the impact area. In order to calculate the population within this area, the average population density of the eMalahleni Local Municipality was calculated 
(159 persons per $\mathrm{km}^{2}$ ), which compares well with the value of 100 persons per $\mathrm{km}^{2}$ given in the AQIA for the majority of the maximum GLC zone (Thomas and Scorgie, 2006). Multiplying the average population density with the total area covered in the zone gives the total affected population of 312450 .

\subsection{Pollution impacts}

To link the incidence of health damages to pollutant concentrations, ERFs are needed. ERFs relate the quantity of pollutant that affects a receptor to the physical impact on that receptor (Rabl, 2011). In general, epidemiological studies report the incidence of illness in terms of relative risk, requiring calculations to assess the ERFs in terms of relative risk values. The expected outcomes are given by Sakulniyomporn et al. (2011:3467) and Thomas and Scorgie (2006:2.16), based on the assumption of zero-threshold linear ERFs.

$$
\begin{aligned}
& E R F(r, C(r, Q))=S E R F(r) \times C(r, Q) \\
& S E R F=I R R \times \text { Baseline } \times F_{P Q P}
\end{aligned}
$$

$C(r, Q)$ represents the average incremental change in ground-level concentration $\left(\mu \mathrm{gm}^{-3}\right)$ at position vector $r$ and emission rate $Q$. The slope, SERF, is calculated from equation (2). IRR refers to the increment of relative risk (percent $/ \mathrm{Mgm}^{-3}$ ), which represents the marginal health risk of pollutant concentrations. The baseline rate is the nominal rate of occurrence of the considered disease, and $F_{P O P}$ denotes the fraction of the population at risk of said disease, typically based on age-specific groups.

When estimating the health cost associated with air pollution, the problem that arises is that relatively high doses are needed in order to obtain observable non-zero epidemiological responses - unless the sample is very large. The required doses are usually far in excess of typical ambient concentrations (Rabl, 2011). Therefore, by definition, lower doses are without effect. Furthermore, the susceptibility of individuals to harmful chemicals can vary widely. This variation comes about as a result of different lifestyles, varying diets, or other exposures and pre-existing health outcomes that may contribute to the effect. These differences make establishing thresholds for a large diverse population difficult (Bull, 2001: 2-3). Consequently, studies which aim to monetise the externalities related to air pollution will often include the zero-threshold assumption (Hainoun et al., 2009; Sakulniyomporn et al., 2011). Typically these studies would also be conducted on a national level to ensure a large population size. In cases where the costs are localised, the population in that area would be more homogenous than a national population, resulting in the inability to use the zero-threshold assumption.
Kusile is situated in the eMalahleni municipality where mining activity is prominent. Mining relies greatly on a migrant workforce for its labour supply with migrant workers originating from all over South Africa. These migrant workers would have been exposed to a variety of different environmental and social factors and it is this variable characteristic which would bring needed heterogeneity to the local population. Therefore, the zero-threshold is deemed appropriate for this analysis.

The scope of health issues related to air pollution is broad, yielding a large number of health concerns linked to air pollution. Since it is not feasible to include every single ailment, only the following health issues are considered (Sakulniyomporn et al., 2011): chronic bronchitis (CB) in adults; respiratory hospital admission (RHA); cardiovascular hospital admissions (CHA); emergency room visits (ERV); acute bronchitis ( $\mathrm{AB}$ ) in children; asthma attacks (ASA) in children; asthma attacks (ASA) in adults; restricted activity days (RAD) in adults; and days with acute respiratory symptoms (ARS). Lung cancer is also considered.

The response of populations to various pollutants is well documented for the developed world; however, fewer studies have attempted to quantify these responses in developing countries. Table 9 provides a summary of the incident rates used in this study. Note that for all outcomes other than cancer, central, low and high values are reported, based on Sakulniyomporn et al. (2011). For lung cancer, guidelines given by the AQIA are used (Thomas and Scorgie, 2006) as indicated in Table $10 .{ }^{11}$ Response to various pollutants is measured in terms of incident rates or risk factors (Van Horen, 1996; Sakulniyomporn et al., 2011), where, for example, if the risk factor for mortality due to inhalation of specimen $\mathrm{X}$ is $3.3 \times 10^{-6}$, one person in $3.3 \times 10^{-6}$ will die for every $1 \mu \mathrm{gm}^{-3}$ increase in the concentration of specimen $\mathrm{X}$.

\subsection{Costs}

By assigning a monetary value to the health costs, one is better able to compare the effects of different health impacts, which often have different units. Given its intangibility, valuing health impacts or health damage costs is complex (Sakulniyomporn et al., 2011). Popular methods include the willingness-to-pay (WTP) and cost-of-illness (COI) approaches (Van Horen, 1996), as well as qualityadjusted life years (QALYs) and disability-adjusted life years (DALYs). A monetary value of the total impact is found by multiplying the number of cases by the unit cost of the specific case and summing over the range of chosen health outcomes.

As yet, unit health costs have not been identified for South Africa. Therefore, Hainoun et al. (2009) is followed. When costs are not readily available, the unit costs determined in other nations can be mul- 
Table 9: Summary of incidence rates for selected health issues Source: (a) Sakulniyomporn et al. (2011: 3476); (b) Thomas and Scorgie (2006: 2.16)

\begin{tabular}{|c|c|c|c|c|c|}
\hline & \multirow[t]{2}{*}{ Health endpoint } & \multirow[t]{2}{*}{ Pollutant } & \multicolumn{3}{|c|}{ Incident rate (case/person year $\mu \mathrm{gm}^{-3}$ ) } \\
\hline & & & Low & Central & High \\
\hline \multirow[t]{6}{*}{ Mortality $^{a}$} & Fatal cancer ${ }^{b}$ & As & $1.50 \mathrm{E}-03$ & $3.30 \mathrm{E}-03$ & $4.30 \mathrm{E}-03$ \\
\hline & Fatal cancer ${ }^{b}$ & $\mathrm{CrVI}$ & $1.10 \mathrm{E}-02$ & $7.10 \mathrm{E}-02$ & $1.50 \mathrm{E}-01$ \\
\hline & Fatal cancer $\mathrm{b}$ & $\mathrm{Pb}$ & $\mathrm{N} / \mathrm{A}$ & $\mathrm{N} / \mathrm{A}$ & $1.20 \mathrm{E}-05$ \\
\hline & Fatal cancer $\mathrm{b}$ & $\mathrm{Ni}$ & $2.40 \mathrm{E}-04$ & $2.60 \mathrm{E}-04$ & $3.80 \mathrm{E}-04$ \\
\hline & Premature death & $\mathrm{PM}_{10}$ & $4.52 \mathrm{E}-06$ & $6.88 \mathrm{E}-06$ & $9.30 \mathrm{E}-06$ \\
\hline & Premature death & $\mathrm{SO}_{2}$ & 4.40E-07 & 8.86E-06 & $1.74 \mathrm{E}-05$ \\
\hline \multirow[t]{11}{*}{ Morbidity $^{a}$} & CB in adults ( $\geq 25$ years) & $\mathrm{PM}_{10}$ & 1.30E-06 & $1.41 \mathrm{E}-05$ & $2.79 \mathrm{E}-05$ \\
\hline & RHA & $\mathrm{PM}_{10}$ & $2.27 \mathrm{E}-05$ & $4.54 \mathrm{E}-05$ & $6.81 \mathrm{E}-05$ \\
\hline & RHA & $\mathrm{SO}_{2}$ & $\mathrm{~N} / \mathrm{A}$ & $1.26 \mathrm{E}-05$ & $2.27 \mathrm{E}-05$ \\
\hline & RHA & $\mathrm{NO}_{2}$ & $\mathrm{~N} / \mathrm{A}$ & N/A & $2.02 \mathrm{E}-05$ \\
\hline & $\mathrm{CHA}$ & $\mathrm{PM}_{10}$ & $2.62 \mathrm{E}-05$ & $4.72 \mathrm{E}-05$ & $6.81 \mathrm{E}-05$ \\
\hline & ERV & $\mathrm{PM}_{10}$ & $1.12 \mathrm{E}-05$ & $4.11 \mathrm{E}-05$ & $7.48 \mathrm{E}-05$ \\
\hline & $\mathrm{AB}$ in children $(<25$ years $)$ & $\mathrm{PM}_{10}$ & $1.94 \mathrm{E}-05$ & $4.41 \mathrm{E}-05$ & $7.23 \mathrm{E}-05$ \\
\hline & ASA in children ( $<15$ years) & $\mathrm{PM}_{10}$ & 3.67E-04 & $5.98 \mathrm{E}-04$ & $8.43 \mathrm{E}-04$ \\
\hline & ASA in adults ( $\geq 15$ years) & $\mathrm{PM}_{10}$ & $4.26 \mathrm{E}-05$ & $8.74 \mathrm{E}-05$ & $1.32 \mathrm{E}-04$ \\
\hline & RAD in children ( $\geq 18$ years) & $\mathrm{PM}_{10}$ & $2.90 \mathrm{E}-02$ & $5.80 \mathrm{E}-02$ & $9.10 \mathrm{E}-02$ \\
\hline & ARS & $\mathrm{PM}_{10}$ & $2.20 \mathrm{E}-01$ & 3.00E-01 & 7.40E-01 \\
\hline
\end{tabular}

Table 10: Summary of cancer incidence rates for selected compounds Source: Thomas and Scorgie (2006: 2.16)

\begin{tabular}{lccccc}
\hline Compound & \multicolumn{2}{c}{ Incident rate (case/person year $\mu \mathrm{gm}^{-3}$ ) } & \multicolumn{2}{c}{ Cancer classification } \\
\hline & California EPA & WHO Inhalation & US-EPA IRIS & IARC & US-EPA $^{1}$ \\
\hline Arsenic, inorganic & $3.30 \mathrm{E}-03$ & $1.50 \mathrm{E}-03$ & $4.30 \mathrm{E}-03$ & 1 & $\mathrm{~A}$ \\
\hline Cadmium & $4.20 \mathrm{E}-03$ & - & $1.80 \mathrm{E}-03$ & $2 \mathrm{~A}$ & $\mathrm{~B} 1$ \\
\hline Chromium VI, particulates & $1.50 \mathrm{E}-01$ & $1.1 \mathrm{E}-2$ to $13 \mathrm{E}-2$ & $1.20 \mathrm{E}-02$ & 1 & $\mathrm{~A}$ \\
\hline Lead & $1.20 \mathrm{E}-05$ & - & - & $2 \mathrm{~B}$ & $\mathrm{~B} 2$ \\
\hline Nickel and nickel compounds & $2.60 \mathrm{E}-04$ & $3.80 \mathrm{E}-04$ & $2.40 \mathrm{E}-04$ & 1 & $\mathrm{~A}$ \\
\hline Nickel sulphate & $4.90 \mathrm{E}-04$ & - & $4.80 \mathrm{E}-04$ & 1 & $\mathrm{~A}$ \\
\hline
\end{tabular}

Note:

1. Cancer classifications:

A: Human carcinogen

B: Probable human carcinogen. There are two sub-classifications:

B1: Limited human data from epidemiological studies.

B2: Sufficient evidence from animal studies and for which there is inadequate or no evidence from human

epidemiological studies.

C: Possible human carcinogen.

D: Not classifiable as to human carcinogenicity.

E: Evidence of non-carcinogenicity for humans.

tiplied by the ratio of Purchasing Power Parity GNI (PPPGNI) between the two nations. This adjustment accounts for income differences, although it may not provide an exact health cost. Essentially, this is an application of the benefit transfer approach, and can provide a good estimate of the cost range. ${ }^{12}$

$$
U_{v}^{S A}=U_{v}^{R} \times\left(\frac{P P P^{S A}}{P P P^{R}}\right)^{\gamma}
$$

$U_{V}$ refers to the unit value in a specific country $-S A$ for South Africa and $R$ for a reference country PPP is the gross national income (GNI) per capita adjusted for purchasing power parity and $\gamma$ represents the income elasticity, set to 1 . While the benefit transfer approach is a useful tool for determining costs where these would otherwise not be known, this methodology should not be seen as a valuation of a life - merely the potential lifetime income lost due to the death of an individual. Since income levels differ across countries, as shown in 
Table 11, the income lost due to death (premature or otherwise) will also differ between countries. This is, however, no reflection on the relative importance of a life in one country compared to a life in another country. To adequately account for the full value of a life, albeit economic, social or otherwise, a multidisciplinary approach is required. ${ }^{13}$

Table 11: GNI per capita for selected regions and countries

Source: World Bank

\begin{tabular}{lr}
\hline Region & GNI per capita $(U S \$) ~ 2010$ \\
\hline China & 4270 \\
\hline Germany & 43110 \\
\hline European Union & 38524 \\
\hline India & 1330 \\
\hline The Netherlands & 49050 \\
\hline South Africa & 6090 \\
\hline Sub-Saharan Africa & 1187 \\
\hline United Kingdom & 38370 \\
\hline United States & 47390 \\
\hline World & 9136 \\
\hline
\end{tabular}

The health cost will be expressed in terms of cents per $\mathrm{kWh}(\mathrm{c} / \mathrm{kWh})$ of electricity produced. Since no South African costs are available, the benefit transfer method is employed. Calculations of $U_{V}$ for each disease is determined from United States (US) and Canadian studies. Equation (3) requires PPP values for South Africa, the US and Canada; 2010 PPP values are used, derived from World Bank data and expressed in terms of gross national income (GNI) based on PPP. The PPP values are given as $\$ 10280$, $\$ 47020$ and $\$ 38310$ for South Africa, the US and Canada, respectively. The Rand/US\$ and Rand/C $\$$ exchange rates for 2010 is quoted as the middle rate for 2010 , as provided by the South African Reserve Bank (SARB) R7.3222/1US\$ and R7.1073/1C\$. Mortality and morbidity costs given in Sakulniyomporn et al. (2011) and Büke and Köne (2010) are converted back to their original values, updated to 2010 values and used to calculate the unitary cost estimations for South Africa; see Table 12. In the case of lung cancer, costs are available for fatal and nonfatal cancers. This analysis gives the cost of all lung cancer cases in terms of fatal case costs, as this gives the maximum cost for a case of lung cancer.

\section{Results}

The incident rates give an indication of the marginal effect of ambient pollution on affected people. The calculation of the effect, EFF, is based on incident rates, population data and additional pollutant contributions from Kusile and equation (4), developed in Vrhovcak et al. (2005).
Table 12: The unitary costs of health impacts

Source: (a) Sakulniyomporn et al. (2011: 3476); (b) Büke \& Köne (2010: 1-5)

\begin{tabular}{lrc}
\hline Health endpoint & Cost $(R, 2010)$ & Estimation \\
\hline Mortality $^{a}$ & & \\
\hline Fatal cancer ${ }^{b}$ & 15630357 & WTP \\
\hline Premature & & \\
\hline Morbidity ${ }^{\text {a }}$ & 687052 & WTP \\
\hline CB in adults $(\geq 25$ years $)$ & 37974 & COI \\
\hline RHA & 4066 & COI \\
\hline CHA & 1410 & COI \\
\hline ERV & 895 & COI \\
\hline AB in children $(<25$ years $)$ & 99 & COI \\
\hline ASA in children $(<15$ years $)$ & 106 & WTP \\
\hline ASA in adults $(\geq 15$ years $)$ & 168 & WTP/COI \\
\hline RAD in children $(\geq 18$ years $)$ & 32 & WTP \\
\hline ARS & &
\end{tabular}

$$
E F F=\text { Conc } \times \text { Dens } \times \text { Area } \times \text { Rate }
$$

Conc refers to the concentration of pollutants, Density and Area refer to the population density and surface area $\left(\mathrm{m}^{2}\right)$ of the area in question, and Rate refers to the incident rates. Cost calculations were done using the low, central and high estimates of the incident rates, while the actual costs are found by multiplying the cost for each impact by the corresponding number of cases and summing the costs.

The unit externality cost, expressed as $\mathrm{c} / \mathrm{kWh}$, is estimated and a summary of these findings is provided in Table 13. Based on this information, Kusile's localised health-related externality cost is estimated to be in the range of $0.09 \mathrm{c} / \mathrm{kWh}$ to $6.08 \mathrm{c} / \mathrm{kWh}$, which compares well with the estimates of the studies depicted in Table 1. Differences are, however, expected as this study was confined to the GLC, whereas the other studies considered the entire national impact. This health cost represents an additional cost over and above the current electricity price of approximately $41 \mathrm{c} / \mathrm{kWh}$.

\section{Discussion and conclusion}

This analysis considers Kusile's air pollution health impacts. It does not consider OHS related costs associated with the operation of Kusile, because the necessary information is not yet available. Furthermore, although fly ash from ash dumps and coal storage piles contribute significantly to ambient PM concentrations, nothing is known about the characteristics of these ash dumps; therefore, health costs related to ash dumps are only partly incorporated by the inclusion of PM in the health cost.

While a large number of health impacts have been included, the list is by no means exhaustive. A 
Table 13: The annual health cost associated with Kusile

\begin{tabular}{lcccccc}
\hline Scenario & \multicolumn{3}{c}{ 0\% Efficiency } & \multicolumn{3}{c}{$90 \%$ Efficiency } \\
\hline Stack height & A1 $(150 \mathrm{~m})$ & $C 1(220 \mathrm{~m})$ & $E 1(300 \mathrm{~m})$ & A1 $(150 \mathrm{~m})$ & C1 $(220 \mathrm{~m})$ & E1 $(300 \mathrm{~m})$ \\
\hline Total cost $(\mathrm{R} \mathrm{m})$ & $102.35-2312.61$ & $88.96-1782.19$ & $79.40-1403.32$ & $36.86-588.24$ & $36.86-588.24$ & $34.95-512.47$ \\
\hline $\mathrm{c} / \mathrm{kWh}$ & $0.27-6.08$ & $0.23-4.69$ & $0.21-3.69$ & $0.10-1.55$ & $0.10-1.55$ & $0.09-1.35$ \\
\hline
\end{tabular}

Table 14: The total annual health cost associated with Kusile for low, central and high incidence rates

\begin{tabular}{|c|c|c|c|c|c|c|c|}
\hline & \multirow{2}{*}{$\begin{array}{c}\text { Scenario } \\
\text { Stack height }\end{array}$} & \multicolumn{3}{|c|}{$0 \%$ Efficiency } & \multicolumn{3}{|c|}{$90 \%$ Efficiency } \\
\hline & & A1 (150m) & C1 (220m) & E1 (300m) & A1 (150m) & C1 (220m) & E1 (300m) \\
\hline \multicolumn{8}{|c|}{ Total cost ( $R$ million) } \\
\hline \multirow[t]{3}{*}{ GLC } & Low & 102.35 & 88.96 & 79.40 & 36.86 & 36.86 & 34.95 \\
\hline & Central & 1196.79 & 926.51 & 733.45 & 308.83 & 308.83 & 270.22 \\
\hline & High & 2312.61 & 1782.19 & 1403.32 & 588.24 & 588.24 & 512.47 \\
\hline \multirow[t]{3}{*}{ Phola Low } & Low & 11.18 & 10.96 & 10.81 & 10.41 & 11.31 & 10.37 \\
\hline & Central & 37.34 & 32.89 & 29.92 & 21.77 & 23.24 & 21.02 \\
\hline & High & 65.37 & 56.64 & 50.81 & 34.81 & 37.01 & 33.35 \\
\hline \multirow[t]{3}{*}{ Phola High } & Low & 55.23 & 54.13 & 53.40 & 51.38 & 55.88 & 51.19 \\
\hline & Central & 186.01 & 163.77 & 148.94 & 108.16 & 115.55 & 104.45 \\
\hline & High & 326.18 & 282.52 & 253.41 & 173.39 & 184.39 & 166.10 \\
\hline \multicolumn{8}{|l|}{$\mathbf{c} / \mathbf{k W h}$} \\
\hline \multirow[t]{3}{*}{ GLC } & Low & 0.27 & 0.23 & 0.21 & 0.10 & 0.10 & 0.09 \\
\hline & Central & 3.15 & 2.44 & 1.93 & 0.81 & 0.81 & 0.71 \\
\hline & High & 6.08 & 4.69 & 3.69 & 1.55 & 1.55 & 1.35 \\
\hline \multirow[t]{3}{*}{ Phola Low } & Low & 0.03 & 0.03 & 0.03 & 0.03 & 0.03 & 0.03 \\
\hline & Central & 0.10 & 0.09 & 0.08 & 0.06 & 0.06 & 0.06 \\
\hline & High & 0.17 & 0.15 & 0.13 & 0.09 & 0.10 & 0.09 \\
\hline \multirow[t]{3}{*}{ Phola High } & Low & 0.15 & 0.14 & 0.14 & 0.14 & 0.15 & 0.13 \\
\hline & Central & 0.49 & 0.43 & 0.39 & 0.28 & 0.30 & 0.27 \\
\hline & High & 0.86 & 0.74 & 0.67 & 0.46 & 0.49 & 0.44 \\
\hline
\end{tabular}

review of epidemiological literature does, however, suggest that a large proportion of the pollutionrelated causes of disease are included. While lung cancer has been included in the analysis, a future point of departure could be to include cancers of various natures into the cost structure. ${ }^{14}$ Furthermore, this analysis does not consider the effect of pollution on foetuses. In a review of epidemiological research pertaining to the effects of air pollution on fetal health, Glinianaia et al. (2004) conclude that while the existence of causal associations between air pollution and fetal health outcomes is plausible - and despite a growing number of studies which focus on investigating this relationship - associations linking deteriorating fetal health and air pollution are weak. Once a clear relationship has been show between fetal health and air pollution, it is suggested that these health outcomes are also included in the analysis.

Presumably, ignoring these costs yields lower estimates for Kusile and their inclusion would likely increase the $0.09 \mathrm{c} / \mathrm{kWh}$ to $6.08 \mathrm{c} / \mathrm{kWh}$ range reported. Considerable data limitations prompted the use of benefit transfer techniques in order to find estimates of the costs. Once the plant is operational, the proxy data can be replaced with actual data to give a more accurate account of the health damage cost approach. Instead of localising the health cost by restricting the sphere of influence to the zone of maximum GLC, it may also be of value to consider the health costs associated with Kusile on a national, population-wide level. Such an analysis would, however, require more detailed information regarding the dispersion of Kusile's pollutants on a national level. Since Kusile is still in its construction phase, the available dispersion data dictated that only a localised cost calculation be conducted. Simple extrapolation of the data to a national context would not capture the complex dispersion of pollutants and would therefore not adequately - and realistically - reflect that dispersion of the pollutants contained in Kusile's emissions. 
With any study making use of the data transfer method, there is the concern that the original data is not of good quality, or that it may be biased in some way (Boyle and Bergstrom, 1992). Using data from an EIA heighten those concerns, since the EIA is commissioned by a party that may be interested in the project. Unfortunately, a quantitative assessment of the quality of the EIA cannot be done. Instead, it is common practice for the EIA to be subjected to extensive rounds of public and private input, as well as an independent review of the document. The draft EIA was subjected to public scrutiny (Ninham Shand, 2007) and only the potential effect or the air quality on poultry in the region was questioned. This concern was addressed in the final EIA. Furthermore, an independent review of the IEA (Mark Wood Consultants, 2007) concluded that '...the specialist studies are generally well prepared, are clear and provide the necessary basis for an objective evaluation of the overall impact of the project.' Lastly, no major issues were identified in the AQIA documentation. While not guaranteeing the EIA is wholly objective and reliable, the EIA numbers are the only numbers available. However, it should be noted that any errors or omissions in the EIA data will be carried over into this analysis, due to the transfer methodology applied.

\section{Acknowledgements}

The authors would like to acknowledge funding from Greenpeace, although the views expressed herein do not necessarily represent the views of the funding body. The authors would also like to acknowledge comments from James N. Blignaut, Roula Inglesi-Lotz, Nono Nkambule, Kuku Voyi, Jane Olwoch, Melita Steele, Nina Schultz, Rianne Teule, Fiona Musana, and participants at the external costs of coal workshop. All remaining errors are the sole responsibility of the authors.

\section{Notes}

1. Each of the new plants - Kusile and Medupi - is projected to generate $4800 \mathrm{MW}$ of electricity and require 17 million tons of coal annually (AfDB, 2009; Eskom, 2011; Synergistics, 2011).

2. $\mathrm{PM}$ is typically classified into one of three fractions: PM2.5, PM10 and PM > PM10; particles with diameter less than $2.5 \mu \mathrm{m}$, less than $10 \mu \mathrm{m}$ or greater than $10 \mu \mathrm{m}$, respectively.

3. Occupational health and safety (OHS) issues also arise when considering the health impacts of electricity generation cycle. For example, links between electromagnetic fields and leukemia have been uncovered (Theriault et al. 1994). Some studies related to health and mining have also been undertaken (van Horen, 1996; Ross and Murray, 2004; Hermanus, 2007); however, there are no available studies associating PM or other pollutants to workplace accidents, so OHS will not be considered further.

4. Schuman and Cavanagh (1982), measuring abatement costs, and Hohmeyer (1988), applying the topdown approach, are worth noting for being the first of their type. Unfortunately, not all of the data limitations noted in their studies have since been alleviated.

5. South African reliance on coal as a source of power dates back to 1870 , when it was first used in a Kimberley diamond mine.

6. Given its abundance, it comes as no surprise that coal is South Africa's main source of energy, providing over $70 \%$ of the country's primary energy and $93 \%$ of its electricity (Department of Energy, 2010).

7. Carbon monoxide, radionuclides and heavy metals are also likely to impact health. Similarly, there are some indirect externalities related to greenhouse gas emissions, but the effect of climate change on human health is primarily global (Hainoun et al., 2009); therefore, these effects fall outside the scope of this study.

8. The EIA considered numerous sites - sites $\mathrm{X}$ and $\mathrm{Y}$ (Figure 2) emerging as the most preferred; site $\mathrm{X}$ was finally selected.

9. Data availability and quality necessitates the use of only the most common health impacts associated with air pollution and their corresponding pollutants. Particles with diameter smaller than $2.5 \mu \mathrm{m}$ (PM2,5) are included in the broader PM10 definition, and therefore, are not included in the cost analysis to avoid double-counting.

10. The potential health impacts for various heavy metals were also considered in the EIA. Cancer risk, due to heavy metal inhalation, ranged between 1:45million and 1:10million (Ninham Shand, 2007). For mercury, specifically, the highest annual, highest daily and annual average concentrations did not exceed the most stringent of international health standards (Ninham Shand, 2007). Therefore the health cost associated with heavy metal exposure will not significantly contribute to the overall health cost to society of coal-fired electricity generation by the Kusile plant.

11. To provide central, low and high estimates for the incidence rates of lung cancer, the three sets of guidelines given in Table 10 were ranked in order from lowest to highest and assigned to the three categories.

12. Although extending the analysis to make use of the entire income distribution would provide estimates of health impact equity, the necessary data is not available for the sites considered in this analysis.

13. Such an estimation falls beyond the scope of this study.

14. Research on the relationship and causality between ambient pollution levels and the prevalence of certain cancers have yet to give conclusive results and can therefore not be included in the analysis.

\section{References}

African Development Bank (AfDB). (2009). Executive summary of South Africa: environmental impact assessment for the Medupi power plant project of Eskom. Available at: ww.afdb.org/fileadmin/uploads/ 
afdb/Documents/Environmental-and-SocialAssessments/ESIA\%20Ex\%20Summary\%20of\%20M edupi\%20Coal\%20Power\%20Plant\%20July\%201\% 20revised\%20Final-ram-1.pdf (accessed on 7 August 2011)

Baumol, W.J. and Oats, W.E. (1988). Theory of environmental policy. Cambridge: Cambridge University Press.

Bhattacharyya, S. (1997). An estimation of environmental costs of coal-based thermal power generation of India. International Journal of Energy Res, 21: 289 298.

Blignaut, J. (2012). Climate change: the opportunity cost of Medupi and Kusile power stations. Journal of Energy in Southern Africa 23(4): 67-75.

Boyle, K.J. and Bergstrom, J.C. (1992). Benefit transfer studies: Myths, pragmatism, and idealism. Water Resources Research, 28(3): 657-663. [Online] Available at: http://0-www.agu.org.innopac.up.ac.za/ pubs/crossref/1992/91WR02591.shtml (accessed on 24 August 2011).

Büke, T. and Köne, A.C. (2010). Valuing health effects of natural radionuclides released from Yatağan power plant. Energy and Power Engineering, 46: 1 -72 . [Online] Available at: www.scirp.org/journal/ epe (accessed on 16 October 2012).

Bull, R.J. (2001). Thresholds in toxic responses to chemicals and radiation and their use in risk assessment and regulation. [Online] Available at: www.nrwa.org/benefits/whitepapers/risks/risks10/risk 10.doc (accessed on 16 October 2012).

Charola, A.E., Pühringer, J. and Steiger, M. (2007). Gypsum: a review of its role in the deterioration of building materials. Environmental Geology, 52(2): 339-352. [Online] Available at: http://0www.springerlink.com.innopac.up.ac.za/content/ 41534g34621160n4/ (accessed on 24 August 2011).

Department of Energy. (2009). Digest of South African energy statistics 2009. [Online] Available at: www.energy.gov.za/files/media/explained/ 2009\%20Digest\%20PDF\%20version.pdf (accessed on 12 July 2011).

Department of Energy. (2010). South African energy synopsis 2010. [Online] Available at: www.energy.gov.za/files/media/explained/2010/ South_African_Energy_Synopsis_2010.pdf (accessed on 8 July 2011).

Dominici, F., Peng, R.D., Bell, M.L., Pham, L., McDermott, A., Zeger, S.L. and Samet, J.M. (2006). Fine particulate air pollution and hospital admission for cardiovascular and respiratory diseases. Journal of the American Medical Association, 295(10): 1127-1134. [Online] Available at: http://0jama.ama-assn.org.innopac.up.ac.za/content/295/10/ 1127.full.pdf + html (accessed on 24 August 2011).

Dutkiewicz, R.K. and De Villiers, M.G. (1993). Social cost of electricity production. Engineering research, Report for the National Energy Council, Pretoria.

Epstein, P.R., Buonocore, J.J., Eckerle, K., Hendryx, M., Stout III, B.M., Heinberg, R., Clapp, R.W., May, B., Reinhart, N.L., Ahern, M.M., Doshi, S.K. and Glustrom, L. (2011). Full cost accounting for the life cycle of coal. Annals of the New York Academy of Sciences, 1219(February): 73-98. [Online] Available at: http://0-onlinelibrary.wiley.com.innopac.up.ac.za/ doi/10.1111/j.1749-6632.2010.05890.x/pdf (accessed on 12 July 2011).

Eskom. (2011). Eskom Integrated Report 2011. Johannesburg: Eskom.

ETSU. (1995). Externalities of fuel cycles: 'ExternE' project summary report. Report no 1. Harwell: ETSU.

European Commission. (1995). ExternE: Externalities of energy. Vol. 1 - 6. Luxembourg: Office for Official Publications of the European Communities.

European Commission. (1999). ExternE: Externalities of energy. Vol. 1 - 6. Luxembourg: Office for Official Publications of the European Communities.

Faaij, A., Meuleman, B. and Turkenburg, W. (1998). Externalities of biomass based electricity production compared with power generation form coal in the Netherlands. Biomass Bionerg, 14: 125 - 147.

Friedrich, R. and Voss, A. (1993). External costs of electricity generation. Energy Policy, 21(12): 114 - 122.

Glinianaia, S.V., Rankin, J., Bell, R., Pless-Mulloli, T. and Howel, D. (2004). Particulate air pollution and fetal health: A systematic review of the epidemiologic evidence. Epidemiology, 15: 36-45. [Online] Available at:

http://ehs.sph.berkeley.edu/krsmith/CRA/lbw/Gliania naia_2004.pdf (accessed on 16 October 2012).

Hainoun, A., Almoustafa, A. and Aldin, M.S. (2009). Estimating the health damage costs of Syrian electricity generation system using impact pathway approach. Energy, 35(2010): 628-638.

Hermanus, M.A. (2007). Occupational health and safety in mining - status, new developments and concerns. The Journal of the Southern African Institute of Mining and Metallurgy, 107(August): 531 - 538.

Hohmeyer, O. (1988). Social costs of energy consumption. Berlin: Springer Verlag.

Inglesi-Lotz, R. and Blignaut, J. (201s). Estimating the opportunity cost of water for the Kusile and Medupi coal-fired electricity power plants in South Africa. Journal of Energy in Southern Africa 23(4): 76-84.

King, D.M. and Mazzotta, M.J. (2000). Methods, Section 8: Benefit Transfer Method. [Online] Available at: www.ecosystemvaluation.org/benefit_transfer.htm (accessed on 24 August 2011).

Klaassen, G. and Riahi, K. (2007). Internalizing externalities of electricity generation: An analysis with MESSAGE-MACRO. Energy Policy, 35: 815 - 827.

Künzli, N., Kaiser, R., Medina, S., Studnicka, M., Chanel, O., Filliger, P., Herry, M., Horak, F., Puybonnieux-Texier, V., Quénel, P., Schneider, J., Seethaler, R., Vergnaud, J. and Sommer, H. (2000). Public-health impact of outdoor and traffic-related air pollution: a European assessment. The Lancet, 365(9232): 795-801. [Online] Available at: http://0www.sciencedirect.com.innopac.up.ac.za/science? ob=MImg\&_imagekey=B6T1B-43P3TK1-9$\overline{3} \& \_$cdi $=488 \overline{6} \& \_$user $=59388 \& \_$pii $=$ S0140673600026532\&_origin $=\&$ \& coverDate $=$ 09\%2F02\%2F2000\&_sk $=996430767 \&$ view $=$ c\&wchp $=\mathrm{dGLbVzW}-\mathrm{zSkWW} \& \mathrm{md5}=$ 49f116bda5f5da1d77dd192b47420b84\&ie $=/ \mathrm{s}$ (accessed on 12 July 2011). 
Levy, J.I., Baxter, L.K. and Schwartz, J. (2009). Uncertainty and variability in health-related damages from coal-fired power plants in the United States. Risk Analysis, 29: 1000-1014. [Online] Available at: http://0-onlinelibrary.wiley.com.innopac.up.ac.za/doi/ 10.1111/j.1539-6924.2009.01227.x/pdf (accessed on 12 July 2011).

Maddison, D. (1999). The plausibility of the ExternE estimates of the external effects of electricity production. CSERGE Working Paper GEC 99-04. London: University College London and University of East Anglia.

Mark Wood Consultants. (2007). Independent review Eskom's proposed coal fired power station in the Witbank area. Johannesburg: Eskom. [Online] Available at: http://recruitment.eskom.co.za/content/ AnnexSMarkWRevFeb07.pdf (accessed on 15 September 2011).

MPG. (2011). Nkangala District Municipality. [Online] Available at: http://www.mpumalanga.gov.za/munic/ municipality_nkangala.htm\#emalahleni (accessed on 24 August 2011).

Ninham Shand. (2007). Environmental impact assessment process: Proposed coal-fired power station and associated infrastructure in the Witbank area. Final environmental impact report. Sandton: Eskom. [Online] Available at: http://recruitment.eskom.co.za/ content/DEIR 2.pdf (accessed on 15 August 2011).

Nkambule, N.P. and Blignaut, J. (2012). The external costs of coal mining: the case of collieries supplying Kusile power station. Journal of Energy in Southern Africa 23(4): 85-93.

Norman, R., Groenewald, P., Vos, T., Laubscher, R., van Walbeek, C., Saloojee, Y., Sitas, F., Bradshaw, D. and S.A.C.R.A.C. (2007). Estimating the burden of disease attributable to smoking in South Africa in 2000. SAJM, 97(7): 782 -790. [Online] Available at: http://0-www.samj.org.za.innopac.up.ac.za/ index.php/samj/article/viewFile/661/156 (accessed on 25 June 2011).

Oak Ridge National Laboratory and Resources for the Future [ORNL/RfR]. (1995). Estimating the fuel cycle externalities: analytical methods and issues (Reports 2-8). Washington: McGraw-Hill Utility Data Institute.

Ottinger, R.L., Wooley, D.R., Robinson, N.A., Hodas, D.R. and Babb, S. (1991). Environmental costs of electricity. New York: Oceana.

Owen, A.D. (2004). Environmental externalities, market distortions and the economies of renewable energy technologies. The Energy Journal, 25(3): 127-156. [Online] Available at: http://0-

ceem.unsw.edu.au.innopac.up.ac.za/content/ userDocs/Ej2004.pdf (accessed on 12 July 2011).

Pearce, D., Bann, C. and Georgiou, S. (1992). The social cost of fuel cycles report to the UK Department of Trade and Industry. London: HMSO.

Pearce, D. and Turner, R.K. (1990). Economics of natural resources and the environment. Hemel Hempstead: Harvester Wheatsheaf.

Pope III, C.A., Ezzati, M. and Dockery, D.W. (2009). Fine-particulate air pollution and life expectancy in the United States. The New England Journal of Medicine, 360: 376-86. [Online] Available at: http:// 0-www.nejm.org.innopac.up.ac.za/doi/pdf/10.1056/
NEJMsa0805646 (accessed on 24 August 2011).

Rabl, A. (2011). Report n 4 : How Much to Spend for the Protection of Health and Environment: A Framework for the Evaluation of Choices. [Online] Available at: http://www.institut.veolia.org/en/cahiers/ protection-health/impact-analysis/functionsresponse.aspx (accessed on 24 August 2011).

Rafaj, P. and Kypreos, S. (2007). Internalisation of external cost in the power generation sector: analysis with global multi-regional MARKAL model. Energy Policy, 35: 828 - 843.

Ross, M.H. and Murray, J. (2004). Occupational respiratory disease in mining. Occupational Medicine, 54(5): $304-310$.

Rowe, R., Bernow, S., Bird, L., Callaway, J.M., Chestnut, L.G., Eldrige, M.M., Lang, C.M., Latimer, D.A., Murdoch, J.C., Ostro, B.D., Patterson, A.D., Rai, D.A. and White, D.E. (1994). New York State environmental externalities cost study, Report 2: methodology. Albany, New York: RCG/Haigler, Bailly, Inc. \& Empire State Electric Research Corporation.

Rowe, R.D., Chestnut, L.G., Lang, C.M., Bernow, S.S. and White, D.E. (1995). The New York environmental externalities cost study: summary of approach and results. Paper presented at the Workshop on the External Costs of Energy, Brussels, 30 - 31 January.

Sakulniyomporn, S., Kubaha, K. and Chullabodhi, C. (2011). External costs of fossil electricity generation: Health-based assessment in Thailand. Renewable and Sustainable Energy Reviews, 15: 3470 - 3479.

Sarnat, J.A., Schwartz, J., Catalano, P.J. and Suh, H.H. (2001). Gaseous pollutants in particulate matter epidemiology: confounders or surrogates? Environ Health Perspective, 109(10): 1053 - 1061. [Online] Available at: http://0-www.ncbi.nlm.nih.gov.innopac. up.ac.za/pmc/articles/PMC1242083/pdf/ehp0109001053.pdf (accessed on 12 July 2011).

Schreurs, M.A. (2011). Transboundary cooperation to address acid rain: Europe, North America, and East Asia compared. In Dinar, S. (ed.). Beyond resource wars: Scarcity, environmental degradation, and international cooperation. Cambridge, Massachusetts: MIT Press.

Schuman, M. and Cavanagh, R. (1982). A model conservation and electric plan for the Pacific Northwest. Seattle: NCAC.

Scire, J.S., Strimaitis, D.G. and Yamartino, R.J. (2000). A user's guide for the CALPUFF dispersion model (version 5). MA: Earth Tech Inc. [Online] Available at: /www.src.com/calpuff/download/CALPUFF_ UsersGuide.pdf (accessed on 20 August 2011).

Spalding-Fecher, R. and Matibe, D.K. (2003). Electricity and externalities in South Africa. Energy Policy, 31: 721-734. [Online] Available at: http://0-www.sciencedirect.com.innopac.up.ac.za/science?_ob= MImg\&_imagekey=B6V2W-46YXJKX-4-3\&_cdi= $5713 \&$ _user $=59388 \& \_$pii $=$ S0301421502001234\&_origin $=\&$ _coverDate $=$ 06\%2F30\%2F2003\&_s $\bar{k}=999689991 \& v i e w=$ c\&wchp $=\mathrm{dGLzVlb-zSkWb \& md5=}$ 01c733b3fd0700236650f946ba4b2323\&ie=/s (accessed on 25 June 2011).

Spalding-Fecher, R. (2005). Health benefits of electrifica- 
tion in developing countries: a quantitative assessment in South Africa. Energy for Sustainable Development, IX(1): 23 - 32.

Synergistics. (2011). New Largo Colliery - Draft Environmental Scoping Report. Report number S0403/NLC/SR02. Johannesburg: Synergistics.

Theriault, G., Goldberg, M., Miller, A., Armstrong, B., Guénel, P., Deadman, J., Imbernon, E., To, T. Chevalier, A., Cyr, D. and Wall, C. (1994). Cancer risks associated with occupational exposure to magnetic fields among electric utility workers in Ontario and Quebec, Canada, and France: 1970-1989. American Journal of Epidemiology, 139(6): 550 572.

Thomas, R. and Scorgie, Y. (2006). Air quality impact assessment for the proposed new coal-fired power station (Kendal North) in the Witbank area. Sandton: Eskom. [Online] Available at: http:// recruitment.eskom.co.za/content/Airqualitypart1.pdf and http://recruitment.eskom.co.za/content/ Airqualitypart2.pdf (accessed on 15 August 2011).

Thopil, G.A. and Pouris, A. (2010). An overview of the electricity externality analysis in South Africa within the international context. South African Journal of Science, 106(11): 1 - 6. [Online] Available at: http:// 0-search.sabinet.co.za.innopac.up.ac.za/WebZ/ Authorize?sessionid=0\&bad=ejour/ejour_badsearch.html\&portal=ejournal\&next=images/ejour/ sajsci/sajsci_v106_n10_11_a15.pdf (accessed on 10 July 2011).

Turpie, J., Winkler, H. and Midgeley, G. (2004). Economic impacts of climate change in South Africa: a preliminary assessment of mitigated damage costs. In Blignaut, J.N. and De Wit, M.P. (eds). Sustainable options: economic development lessons from applied environmental resource economics in South Africa. Cape Town: University of Cape Town Press.

Van Horen, C. (1996). Counting the social costs: Electricity and externalities in South Africa. Cape Town: University of Cape Town Press and Elan Press.

Vrhovcak, M.B., Tomsic, Z. and Debrecin, N. (2005). External costs of electricity production: case study Croatia. Energy Policy, 33: 1385 - 1395.

Wassung, N. (2010). Water scarcity and electricity generation in South Africa, Part 1: Water use in the coalto-electricity process. Unpublished thesis. University of Stellenbosch, Stellenbosch. [Online] Available at: http://0-scholar.sun.ac.za.innopac.up.ac.za/bitstream/ handle/10019.1/5858/wassung_water_2010.pdf? sequence $=1$ (accessed on 24 August 2011).

Zvereva, E.L., Toivonen, E. and Kozlov, M.V. (2008). Changes in species richness of vascular plants under the impact of air pollution: a global perspective. Global Ecology and Biogeography, 17(3): 305-319. [Online] Available at: http://0onlinelibrary.wiley.com.innopac.up.ac.za/doi/ 10.1111/j.1466-8238.2007.00366.x/pdf (accessed on 24 August 2011).

Received: 30 November 2011; revised 10 October 2012 